\title{
Selection of Optimal Forms of Corporate Governance Model: Genesis and Trends of Selection in the Conditions of Post-Coronavirus Recovery of Economic Potential
}

\author{
Oleg Sudorgin ${ }^{1, *}$, Andrey Strygin ${ }^{1}$, and Ekaterina Karelina ${ }^{2}$ \\ ${ }^{1}$ Moscow Automobile and Road Construction State Technical University, 125319 Moscow, Russia \\ ${ }^{2}$ Moscow State Technological University «STANKIN», 127055 Moscow, Russia
}

\begin{abstract}
Global macroeconomic changes in the growth rates of the world's leading countries in the 21 st century are undergoing significant changes due to the obvious advantages of Asian forms of corporate governance models of the leading BRICS countries, including the Russian Federation. At the same time, based on the short, in comparison with developed market economies, experience of using corporate governance methods in the country, it seems expedient in the process of restoring the national economic potential to its pre-coronavirus level, to use a combination of Asian and a set of European-American models of corporate governance in the near future, what is motivated in this publication, based on the genesis of the formation, transformation and development of corporate governance in Russia.
\end{abstract}

\section{Introduction}

The stabilization of the domestic political and socio-economic situation in Russia at the beginning of the 21st century led to the need to form a National Council on Corporate Governance in 2003, which was directly related to the consequences of property rights in the context of the growth of foreign investment in the country's economy, as well as the rights of property management systems whose interests often conflicted with the interests of the owners [1].

At the same time, the institutionalization of corporate governance in Russia contributed to a greater integration of the country into the system of world economic relations, which, on the one hand, was guaranteed by a stable position and a high rating in the world markets of JSCs with a controlling stake owned by the state, or state corporations such as PJSC "Gazprom", PJSC "NK Rosneft", as well as the state corporation" Rosoboronexport" and some other structures of the state corporation" Rostech", which provide a significant share of revenues to the country's budget, and, on the other hand, contributed to their entry into the number of the first few hundreds of world companies, in which $58 \%$ of assets were controlled by management [2].

\footnotetext{
${ }^{*}$ Corresponding author: sudorginoleg $@$ yandex.ru
} 
As a result, after the socio-economic failure of the 1990s, thanks to the vigorous activity of a number of PJSCs and state corporations in the foreign market, a strong trend of GDP growth and stabilization of the domestic economic situation emerged in Russia, which had a positive effect on the country's world ranking and greater confidence in it coming from foreign investors.

\section{Materials and methods}

At the same time, the independent international expert group "PwC" [3] carried out an analytical forecast of the development of the world economy until the middle of the XXI century, where Russia's position in the international ranking is consistently ranked sixth amid significant dynamic shifts in the system of world economic relations, which is convincingly confirmed by the data presented in Table 1, according to which a stable position of the Russian economy is predicted, in contrast to dynamic shifts in the economic ratings of other countries of the world.

Table 1. Achieved and projected economic rating of the world's leading countries

\begin{tabular}{|c|c|c|c|}
\hline $\begin{array}{c}\text { Country } \\
\text { ranking }\end{array}$ & $\mathbf{2 0 1 5}$ & $\mathbf{2 0 2 5}$ & $\mathbf{2 0 5 0}$ \\
\hline 1 & China & China & China \\
\hline 2 & USA & India & India \\
\hline 3 & India & USA & USA \\
\hline 4 & Japan & Japan & Indonesia \\
\hline 5 & Germany & Germany & Brazil \\
\hline 6 & Russia & Russia & Russia \\
\hline 7 & Mexico & Indonesia & Mexico \\
\hline
\end{tabular}

Source: Forecast by the analytical group «PwC», http://www.pwc.com./world.2050

At the same time, the coronavirus pandemic, which the world faced in early 2020, largely cast doubt on the expected forecasts, which was primarily due not only to a total drop in both the global and national GDP of the leading states (regardless of whether we are talking about the "G7 countries" as the most developed or about the "G20 countries" that unite both the most developed and the most dynamically developing ones), but also with a catastrophic increase in diseases, and at the same time the most significant drop in GDP as a result of lockdowns the first and second waves of this year's pandemic in Brazil, Mexico, India, Germany and Italy. At the same time, despite the policy that excludes partial or regional lockdowns in the United States, as a result of the pandemic, the economy of this country also suffered serious losses. On the contrary, despite the strict quarantine measures being taken in China or Japan, the GDP of both countries quickly stabilized after a slight drop in the first months of anti-epidemiological restrictions. It is interesting to note that also in Russia, thanks to the strict centralization of all anti-epidemiological measures, as well as a significant increase in spending on social support for the population, the country's GDP did not fall as sharply as it did in Europe and America, and realistic forecasts for its recovery suggest growth in the range of $3.3-4.2 \%$ by the end of 2022 .

And this, in turn, allows, firstly, to express some confidence that the forecasts of a stable sixth place for Russia in world macroeconomic ratings look quite realistic, and, 
secondly, to make the assumption that the combination of the so-called "Asian stagnation "and" European dynamic "models of economic development [4], which determined the specificity of the combination of European and Asian models of corporate governance in the country by the beginning of the XXI century, turned out to be quite successful.

\section{Results and discussion}

As we know, the fundamental foundations of the theory of corporate governance as the highest level of management of joint-stock companies were laid by American researchers A. Burleigh and G. Means back in 1932, after the publication of their book "Modern corporation and private property" [5], where the issues of separation of property from management and control in joint stock companies were considered for the first time, which became especially important for reforming the Russian economy in the 1990s [6].

At the same time, if we consider corporate governance as an organizational model, which is designed, on the one hand, to regulate the relationship between the management of companies and their owners, and, on the other hand, to coordinate the often conflicting goals of various stakeholders, ensuring business efficiency, then it turns out that this important concept still does not have its definition in the domestic literature [7], but, being a systemic concept, it has a wide variety of national models [8].

The genesis of the formation of corporate governance models goes back to the period of the formation of the foundations of world economic relations [4], when two types of economic management were clearly formed: the "European" one, based on private entrepreneurship, and, therefore, inevitable risks, but whch provided an opportunity to obtain a high economic effect, and also the "Asian" one, which did not give such high results, but guaranteed stable development, for which it was also called the "Asianstagnation model".

With the formation of the global world economy, both of these principles have significantly determined the three main models of corporate governance against the background of the multinational diversity of its forms.

The first is the American (Anglo-American), or, as it is also called, the outsider model, which is based on a high level of use of market mechanisms of corporate control external to the business structure, which has become widespread in the countries of the Englishspeaking regional world: in the USA, the UK, Australia, New Zealand and Canada.

As a counterbalance, the European (German), or, as it is also called, the insider model exists, which is based on the use of internal methods and resources of business structures, provides them with self-control, which is traditionally typical for most Western European countries.

In general, in the German (European) model, shareholders are rather large holders of stakes in business structures, which significantly reduces the role of the external market, and on the contrary, in the American model, shareholders are mainly small owners, due to the disunity of which the external market for corporate control plays a key role.

With the transition of the Soviet and then the Russian economy to market relations, at the first stage, the country was dominated by some approximation to the American model of corporate governance, but, as the population became impoverished and the GDP fell, and also due to the intensification of economic activities of state corporations and joint-stock companies with predominant state participation, the European (German) model of corporate governance began to receive priority [9]. This situation had double consequences, as noted by D. Stiglitz [10], where the principle of separation of property rights and control is often not recognized when, on the one hand, there is some stabilization due to the growth of control by the state, but, on the other hand, there is an outflow of foreign capital because of concerns regarding property rights under external control. 
The latter circumstance, combined with a multitude of destabilizing factors (concerning both foreign and domestic policies), led to the conclusion that none of these models exists in Russia, and all business development is focused on several models of corporate governance [9], including special growth interest in the so-called Japanese (Asian) model, formed in the post-war period on the basis of industrial and financial groups, or keiretsu, and characterized as a completely closed model based on bank control. This model became a logical transformation of traditional forms of corporate-family business such as zaibatsu in pre-war Japan, which during the Edo period embarked on the path of reforming the country's traditional economic structure and entering the sphere of world economic relations. This model has become widespread in a number of other Asian states, in newly industrialized countries, the so-called "Asian tigers", where it has not always been successfully implemented. [11]. But, nevertheless, in Russia of the current century, interest in it is sharply increasing along with the increasing trend of restructuring business structures, their mergers, acquisitions and bankruptcy [12].

\section{Conclusions}

The consequences of the coronavirus pandemic, which, to one degree or another, had an impact on the economic development of almost all countries of the world, could not but affect the transformation of corporate governance models, which have their own regional specifics. At the same time, the drop in GDP and the inevitably following decline in the living standards of the population inevitably leads to an increase in social protests, as well as a surge in violence, extremist and xenophobic sentiments. In this regard, the search for an effective model or a combination of various models of corporate governance is becoming especially relevant, which really guarantees that the state budget will receive additional tax revenues from business structures, and, therefore, reduce the level of influence of destabilizing factors in the process of restoring the country's economic potential to the pre-coronavirus level.

As practice has shown, measures for socio-economic stabilization and mitigation of the consequences of coronavirus restrictions in Russia brought positive results, but at the same time, financial discipline decreased significantly in a number of regions [13], which entailed "manual control" along the power vertical. In this regard, it is advisable to expand the range of use of the Asian model of corporate governance in combination with the European (for large PJSCs and state corporations) and partly with the American (for small businesses requiring support from the external environment) corporate governance models, which together can actually provide accelerated recovery. economic potential of Russia and the return of its macroeconomic indicators to the pre-coronavirus level [14].

\section{References}

1. A. V. Bukhvalov, J. Rus. Manag. Journ., 3, 15 (2005)

2. A. Klepach, P. Kuznetsov, P. Kryuchkova, Corp. Gov. Rus. J. Econ., 12, 14 (1996)

3. The world in 2050 Analytical forecast of PwC corporation (Pricewaterhouse Copers), https: //www.pwc.com

4. A. V. Strygin, International economics (2008)

5. A. Berle, G. Means, Modern Corporation and Private Property (1932)

6. R. M. Etnov, Corporate governance problems in Russia and regions (2002)

7. Corporate Governance: history and practice. Website of the Financial markets service of the Bank of Russia, http://www.cbr.ru/ 
8. O. V. Lazareva, A. A. Rachinskiy, L. S. Ruzhanskaya, Corporate Governance: Methodological guide for the special course (2003)

9. A. D. Radygin, R. M. Etnov, I. V. Mezheraups, Features of the formation of a national model of corporate governance (2003)

10. J. Stiglitz, Corp. Gov. Fail. Transition J. Econ. Sci. Mod. Rus., 4, 36 (2001)

11. J. Studwell, How Asia Works: Success and Failure in the World's Most Dynamic Region (2016)

12. A. A. Yakovlev, Corp. Gov. Enterprise Restr. Rus. J. HSE Econ. Journ., 6, 24 (2003)

13. Official website of the Ministry of Finance of the Russian Federation, http://www.minfin.ru/

14. L. R. Bilyalova, A. V. Strygin, Tren. Eco. Dev. Rus. J. Fin, Bus., 2, 3 (2020) 